\title{
Effect of Corporate Governance, Information Asymmetry, And Firm Size on Earning Management
}

\author{
Nurainun Bangun, S.E, Ak., M.M., CA., Lecturer of Faculty Economic and Business, Tarumanagara \\ University, Jakarta, nurainunb@fe.untar.ac.id \\ Dr. Rio Monoarfa, SE, M. Si Ak, Lecturer of Faculty Economic, Gorontalo State University, Gorontalo, \\ rio_mono@yahoo.com
}

\begin{abstract}
The purpose of this research is to obtain information by conducting empirical testing on the influence of corporate governance independent variables, Information asymmetry, and firm size on independent earnings management variables in manufacturing companies listed on the Indonesia Stock Exchange (IDX) in the 2016-2018 period. In this study there were 59 manufacturing companies selected and used as samples by using purposive sampling as a sampling technique and testing multiple linear regression analysis. This study explains the results of testing on the variable corporate governance and information asymmetry with the results that show no significant effect on earnings management while the firm size variable shows a positive and significant relationship to earnings management.
\end{abstract}

Keywords: corporate governance, information asymmetry, firm size, earning management.

Received: 04.12.2020 Accepted: 15.01.2021 $\quad$ Published: 04.02.2021

\section{INTRODUCTION}

Financial statements are a means of communication to provide financial information that has been presented by internal parties to outside parties (Kieso, et al. 2019, p. 1-3). The purpose of the company 's financial statements presented to the public interest is to provide information to parties in need related to the company's financial position, the performance of a company, and the cash flow of an entity that can provide benefits to those who need it and can make an economic decision on financial statements obtained (SAK, revised 2016). Information about the profits obtained is a form of measurement of failure or success of the company (Susanto et al, 2017, in Linda and Agustina, 2018, p.45).

Companies that get the profit from the results of investment will encourage managers to improve the quality of company performance through the activity of manipulating corporate profits. Activities in earnings management can be carried out by managers by applying accrual-based accounting policies to achieve company goals (Linda and Agustina, 2018, p.45). Accrual-based accounting allows managers to choose accounting methods based on permissible standards. The action is compiling transactions to change financial statements so that it affects the results of the figures in the company's financial statements called earnings management.

Earnings management according to Healy and Wahlen (1999, in Wiyadi et al, 2015, p.23) contains several aspects. First financial reporting with earnings management is done through an assessment that is estimating the large number of future economic events that can be shown through financial statements, namely the value of the residual fixed assets, estimated economic life, liability for pensions, losses from deferred tax receivables and impairment in value of an asset. In addition, company managers can choose accounting methods in the form of depreciation methods and cost methods. Second, the existence of earnings management in a company can mislead investors regarding the economic performance of a company, so that investors will make decisions incorrectly.

Earnings managementcan be done by raising or lowering the corporate profits. Earnings management can occur because companies have the freedom to choose accounting methods and estimates in accounting that will be presented in financial statements (Bartov, 1993 in Santana and Wirakusuma, 2016, p.1556). There are two types of encouragement in motivating company managers to do earnings management, namely avoiding losses and avoiding a decline in profits.

The first encouragement, avoiding losses is done if the company suffers losses so that it can have an impact on stock prices, loss of trust on the part of investors, encourage tax audits to be carried out by the government. The second encouragement, avoiding a decline in corporate profits this is done so that the profits presented do not experience fluctuations will reduce the impact that is not good for external parties (Santana and Wirakusuma, 2016, p.1556-1557). 
In Indonesia there are cases of companies carrying out earnings management activities such as the first case, Garuda Indonesia in 2019 by reporting the financial performance of fiscal year 2018 to the Indonesia Stock Exchange by posting a net profit of US \$ 809.84 thousand while in 2017 the company reported a net loss of around US \$216.58 million. Garuda Indonesia recognizes the revenue that has not been received in cooperation with Mahata so that it receives a profit in 2018 from the previous loss (www.ojk.go.id, PENG-3 / PM.1 / 2019). The second case, PT Hanson International recognized revenue by the full accrual method in the annual financial statements as of December 31, 2016 for the sale of Plot Ready to Build (KASIBA) with a gross value of Rp.732,000,000,000.-. (www.ojk.go.id, SP 26 / DHMS / OJK / VI / 2019).

Corporate governance is one of the factors that influence earnings management. The structure and mechanism of corporate governance must be in accordance with applicable laws, regulations and ethics. Good corporate governance will be able to improve performance and long-term economic value for investors and stakeholders. According Widyaningsih (2017) states that companies that have family ownership can have a significant effect on earnings management. Research conducted by Indracahya and Faisol (2017) states that coporate governance has a negative and significant effect on earnings management, because earnings management is an action that is done together. Whereas Abdillah, Susilawati, and Purwanto (2016) who conducted research on corporate governance and stated that corporate governance in the proxy audit committee, independent commissioners, and institutional ownership had a negative influence and managerial ownership had a positive influence.

There are several factors that can trigger earnings management, one of which is asymmetric information. Information asymmetry is a concept that recognizes that there are several parties in business transactions that have an information advantage when compared to other parties (Zarah Puspitaningtyas, 2015, p. 35). The information asymmetry in the company is considered to cause earnings management practices. Asymmetry of information contained in a company can encourage the company manager to take action on earnings management activities if the information to be conveyed is related to the performance of the manager himself. In order to reduce the existence of earnings management activities within the company, it can be done to improve the quality of information that will be provided to outside parties (investors).

When the asymmetry of company information is high, there will be opportunities for company managers to perform earnings management activities where outsiders do not have more access to information about the condition of the company so that outsiders cannot oversee the activities carried out by the manager, it can lead to management activities.earnings in the company (Pramesti and Budiasih, 2017, p.207).

There have been several previous studies such as researchers Wiyadi, et al (2015) and Lita, et al (2018) which stated that information asymmetry has a positive influence on management earnings.Whereas researcher Yulius, et al (2019) stated that information asymmetry does not have a significant effect on earnings management.

One factor that can indicate earnings management activities is company size. The size of a company can be described by the total in assets, the total in sales, and the capitalization of a market (Agustia and Suryani, 2018, p.64-65).

The broad market indicates that the company is increasingly known by outsiders with market capitalization so that it has the potential to gain a lot of sales and the company's financial turnover is getting bigger. In addition, the size of assets owned by the company can reflect that the capital obtained from investors is also large (Prasetya and Gayatri, 2016, p.515).

Companies that have a large category of companies will manage their operational activities more transparently (Agustia and Suryani, 2018, pp. 64-65). That is because companies in large categories require large funds as well, in addition large companies can be considered more by outside parties such as investors, government and creditors. Thus the size of a company is considered to have an influence with the existence of earnings management activities in a company (Wahyono et al, 2019).

There are several different views regarding the research of company size variables, namely the results of the study (Ali et al 2015); (Nalarreason et al 2019) states that firm size has a significant positive effect on earnings management. But according to the results of research from (Wahyono et al, 2019); (Mayasari et al, 2019) states that firm size does not have a significant effect on earnings management.

\section{THEORITICAL REVIEW}

\section{Agency Theory}

Agency theory describes the agency relationship, which is a contract in which one or more principals in the form of shareholders as the person who rules to perform a service on behalf of the principal and by 
authorizing the management (agent) to provide the best decision for shareholders (principal). Managers and investors who have different interests will also make different decisions which will eventually lead to conflicts of interest between managers and investors (Jensen and Meckling, 1976, in Wiyadi et al 2015). Management is a contracted party by the principal who works for the interests of shareholders, so management must be able to account for the work it does to shareholders. If management (agent) does not prioritize the duties assigned by the investor (principal), then it can cause an agency conflict in eventually will trigger agency costs (Aljana and Purwanto, 2017, p. 2). If there is managerial in the company it will reduce agency costs, because agents and principals have the same goal in maximizing company quality.A problem that arises between agent and principal can be overcome by agency theory (Adam, 1996 in kurniawansyah, et al, 2018).

\section{Signaling Theory}

Signaling Theory is closely related to the information asymmetry in which there is a disclosure of signals within the company between management (agent) and investor (principal). This is important and must be considered so that the company can successfully maintain and obtain capital from investors. This signaling theory can be used as an explanation of why a company has a desire to provide information related to financial statements to external parties (investors). The desire of the company to provide information related to financial statements to outsiders is that there is information asymmetry between the management and external parties (investors) where the management is more aware of the company's condition than outsiders (creditors, investors). For outsiders who do not have information that more about the condition of the company will tend to protect themselves by giving a lower price to the company. Increasing the value in the company can be done by reducing information asymmetry. Giving signals to outsiders in the form of information related to audited company financial statements is a way that companies can do to reduce the information asymmetry (Fitriana and Febrianto, 2017, p.3)

\section{Positive Accounting Theory}

Positive Accounting Theory (PAT) is a theory that is used to explain a process using the ability, understanding and accounting policies that are most appropriate in dealing with certain conditions and conditions in the future (Richard Wiratama and Marselinus Asri, 2020). In a paper entitled " Positive Accounting Theory: A Ten Years Perspective " (1990) by Watt and Zimmerman in (Richard Wiratama and Marselinus Asri, 2020) suggests the existence of three hypotheses from PAT are as follows: The bonus plan hypotheses, the company will choose the procedure appropriate accounting for transferring future income to the current period with the aim of receiving bonuses by the company. The debt agreement hypothesis, companies will choose this hypothesis by reporting changes in earnings in the future period to the present if the company violates the accounting principles based on the agreement in debt. The debt agreement hypothesis, companies will choose accounting procedures to reduce profits by diverting current income into the future in order to avoid tax policy by the government.

\section{The effect of corporate governance, information asymmetry and firm size on earnings management.}

According to the OECD (2004) in Wimelda and Chandra (2018) defining that corporate governance as a set of relationships between company management, company boards, shareholders, and other relevant stakeholders. Corporate Governance also secures company assets and increases the value of long-term investments. The board of directors, shareholders and stakeholders will monitor management to reduce the possibility of conflicts of interest between agents and principals. Corporate governance practices can reduce companies in making earnings management.

Man, et.al. (2013) in Wimelda and Chandra (2018) mechanisms in corporate governance can be divided in two ways, namely internal corporate governance mechanisms and external corporate governance mechanisms. Therefore, corporate governance can be concluded as a system and structure implemented by the company so that the company can increase the value of long-term investment by taking into account the interests of the stakeholders.

Information asymmetry is a concept that recognizes that there are several parties in business transactions that have an information advantage when compared to other parties (Zarah Puspitaningtyas, 2015 , p. 35). The information asymmetry in the company is considered to cause earnings management practices. There is a close relationship between information asymmetry and the level of earnings management practices (Richardson 1998, in Pramesti and Budiasih, 2017, p.207). Asymmetry of information contained in a company can encourage the company manager to take action on earnings management activities if the information to be conveyed is related to the performance of the manager 
himself. In order to reduce the existence of earnings management activities within the company, it can be done to improve the quality of information that will be provided to outside parties (investors).

The quality of the financial statement information provided can reflect the large level of earnings management practices in the company. When the asymmetry of company information is high, there will be opportunities for company managers to perform earnings management activities where outsiders do not have more access to information about the company's condition so that outsiders cannot oversee the activities carried out by the manager, it can lead to management activities profit in the company (Pramesti and Budiasih, 2017, p.207). The existence of information asymmetry in the company can provide an opportunity for managers to maximize the value of the company by giving a signal to investors regarding the conditions in the company. Disclosure of information in accounting is a form of signal that can be given by company managers (Manggau, 2016, p.104).

According to Zarah Puspitaningtyas (2015) Information asymmetry within a company is divided into two types, namely: first, Adverse Selection is a type of information asymmetry in which one party or more like a manager or another party gets more information about the condition of the company than external parties such as investors. Second, Moral Hazard is a type of information asymmetry carried out by a party or more like a company manager where the actions to be taken are unknown to investors. With that, the manager can do things that violate ethics and contracts that should not be done without the knowledge of external parties.

Company size is a scale of comparison between large companies and small companies which can be classified by looking at the amount of assets, the size of the log, the amount of sales and market capitalization. Large companies will issue new shares to sell widely to increase sales growth in the company when compared to small companies. The size of an increasingly large company will likely require funding from external parties. Large-scale companies tend to need larger funds and one alternative way to obtain funds is to make loans or debt. It can be said that large companies will have a greater likelihood of using debt as an alternative fundraising compared to small scale companies (Yofi and Elly, 2018 in Wahyono et al, 2019).

The increasing amount of funds that must be obtained encourages earnings management activities undertaken by the company. Besides the large size of a company shows the better financial turnover and the number of assets owned so that it will attract investors to invest their capital. It can also trigger earnings management activities within the company (Asyiroh and Hartono, 2019). Research results from (Ali et al 2015); (Nalarreason et al 2019) states that company size has a significant positive effect on earnings management.

The existence of this relationship shows conformity with agency theory where the asymmetry of information in the company can encourage managers to carry out earnings management activities for their own benefit with the aim of obtaining profits. In addition, the relationship of company size shows conformity with the signal theory in which there is an impetus for company managers to give signals to outsiders in the form of company conditions and information related to audited financial statements to outsiders (Asyiroh and Hartono, 2019).

The following framework is presented in this research, namely:

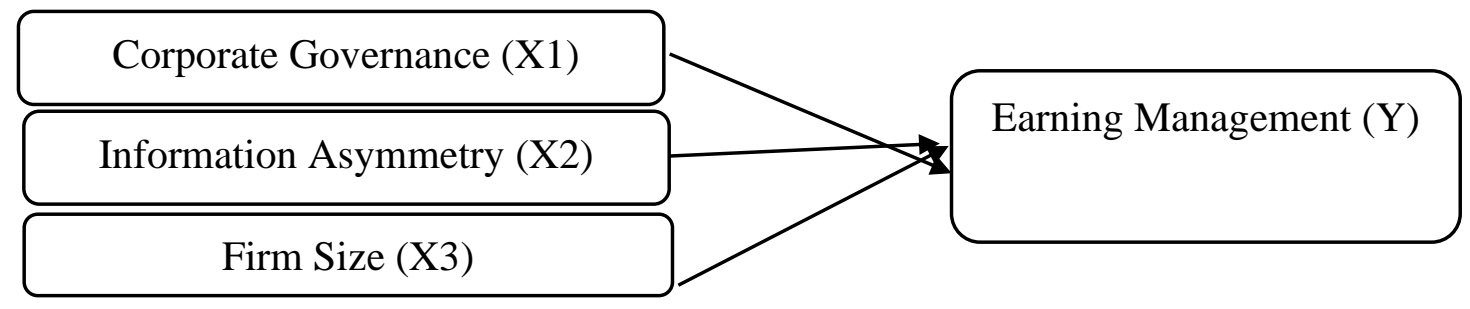

The following are hypotheses based on the previous framework:

Ha1:corporate governance has a positive and significant effect on earnings management.

Ha2:Information Asymmetry has a positive and significant impact on earnings management.

Ha3: firm size has a positive and significant effect on earnings management.

\section{METHODOLOGY}

This study uses the object of independent variables namely Corporate Governance, Information Asymmetry, and Firm Size. The dependent variable used is Earning Management. The data in this study are secondary data taken from manufacturing company financial statements found on the official website of the Indonesia Stock Exchange (IDX). This study has subjects in the form of all companies listed on the 
Indonesia Stock Exchange (IDX) in 2016-2018. The following are some of the sample selection criteria determined in this study as follows: (1) Manufacturing companies listed on the Indonesia Stock Exchange (IDX) during the 2016-2018 period. (2) Currency presented in the financial statements must be in Rupiah for the period 2016-2018. (3) Manufacturing companies issue consolidated financial statements for the period 2016-2018. (4) Manufacturing companies earn profits consistently during the 2016-2018 period.

The operationalization of variables in this study consists of two variables: the dependent variable used is earnings management and the independent variables used are corporate governance, information asymmetry, and firm size.

\section{Dependent Variable}

Discretionary Accruals are used as a proxy for calculating earnings management using a modified Jones model. Empirically the values contained in Discretionary Accruals (DA) can produce zero, positive, or negative. The stages of the formula for calculating earnings management using the Discretionary Accrual (DA) method require Sulistiyanto (2008) in Agustia and Suryani (2018) are as follows:

\section{First step}

The first step is determining the value of Total Accrual (TAC) with the following formula:

$$
\text { TACit }=\text { NIit }- \text { CFOit }
$$

\section{Second Step}

The second step is the Total Accrual estimated by the Ordinary Least Square (OLS) regression equation with the following formula:

$$
\frac{T A C i t}{\text { Ait }-1}=\beta 1\left(\frac{1}{\text { Ait }-1}\right)+\beta 2\left(\frac{\Delta R E V i t}{\text { Ait }-1}\right)+\beta 3\left(\frac{\text { PPEit }}{\text { Ait }-1}\right)+\mathrm{e}_{\mathrm{it}}
$$

\section{Third Step}

The third step is calculating Non Discretionary Accruals (NDAC) using the following formula:

$$
\text { NDACit }=\beta 1\left(\frac{1}{A i t-1}\right)+\beta 2\left(\frac{\triangle R E V i t-\triangle R E C i t}{A i t-1}\right)+\beta 3\left(\frac{\text { PPEit }}{\text { Ait }-1}\right)
$$

\section{Fourth Step}

The fourth step is calculating Discretionary Accruals (DAC) using the following formula:

$$
\text { DACit }=\left[\frac{\text { TACit }}{\text { Ait }-1}\right]-\text { NDACit }
$$

Information:

TACit : Total accruals at company $\mathrm{i}$ in the $\mathrm{t}$ period.

NIit : Net income in company i in period $t$.

CFOit $\quad:$ Operating Cash Flow at company i in period $t$.

DACit : : Discretionary accruals at company $\mathrm{i}$ in the period $\mathrm{t}$.

NDACit : Non-Discretionary Accruals in company $i$ in the period $t$.

Ait-1 : Total assets in company $\mathrm{i}$ in the $\mathrm{t}-1$ period (previous year).

$\beta 1, \beta 2, \beta 3 \quad$ : Regression Coefficient.

$\triangle$ REVit $\quad$ : Changes in revenue at company i in the period $\mathrm{t}-1$ (previous year).

$\triangle$ RECit $\quad$ : Change in receivable at company i in the period $\mathrm{t}-1$ (previous year).

PPEit $\quad$ : Property, Plant, Equipment in company $\mathrm{i}$ in the period $\mathrm{t}$.

\section{Independent Variable}

Corporate governance in this study can be proxied by independent commissioners. According to Agustia (2013) and Rahmawati (2013) in Wimelda and Chandra (2018), independent commissioners can be calculated using the following formula:

$$
\text { Independent Commissioner }=\frac{\text { Anggota dewan } \text { komisarisindependen }}{\text { Total } \text { dewan } \text { komisaris }}
$$




\section{Information Asymmetry}

Information Asymmetry is an information gap related to company perspective that is more owned by managers than information obtained by external parties or investors (Wiyadi, et al, 2015, p.25). Asymmetry information can be measured using the Bid Ask Spread proxy which is calculated using the following formula:

SPREADi, $\mathrm{t}=\frac{(\text { aski, } \mathrm{t}-\text { bidi, } \mathrm{t})}{\{(\text { aski, } \mathrm{t}+\text { bidi, } \mathrm{t}) / 2\}} \mathrm{X} 100$

Information:

SPREADi, $\mathrm{t}$ : Relative bid ask spread (the difference between the buying price (bid) of shares and the selling price (ask) of shares in company i on the t-day.

aski, $\mathrm{t}$

: The highest ask price in company I on the t.

bidi, $\mathrm{t}$

: The lowest bid price in company $i$ on the $t$.

Firm Size. Firm Size. Firm size in this study was measured using total assets owned by the company. Based on Arianti's research. et.al. (2020), the firm size formula is as follows:

Firm Size $=$ Ln(Total Asset $)$

Multiple linear regression can be used to test whether it has the effect of two or more independent variables on one dependent variable. This model can use the ordinary least square method because it uses three independent variables and one dependent variable (Ghozali and Ratmono, 2017). In this research the multiple linear regression equation model can be described as follows.

$Y=\alpha+\beta_{1} X_{1}+\beta_{2} X_{2}+\beta_{3} X_{3}+\varepsilon$

Keterangan:

$\begin{array}{ll}\mathrm{Y} & =\text { Earning Management } \\ \alpha & =\text { Constant coefficient } \\ \beta_{1}, \beta_{2}, \beta_{3} & =\text { Regression coefficient } \\ \mathrm{X}_{1} & =\text { Corporate Governance } \\ \mathrm{X}_{2} & =\text { Information Asymmetry } \\ \mathrm{X}_{3} & =\text { Firm Size } \\ \varepsilon & =\text { Error }\end{array}$

Data is managed using the Microsoft Excel 2019 program and testing is done using the E-views 10 program.

\section{Statistical Test Results}

\section{Descriptive statistics}

Descriptive statistical tests are obtained by using the E-Views 10 program and will get results from the mean (mean), middle (median), highest (maximun), lowest (minimum), and standard deviation values to make it easier to understand. The following are the results of the descriptive statistical analysis test related to the independent and dependent variables in this study.

Table 1. Descriptive Statistics

\begin{tabular}{|l|l|l|l|l|}
\hline & Y & $\mathrm{X} 1$ & $\mathrm{X} 2$ & $\mathrm{X} 3$ \\
\hline Mean & 0.020403 & 0.410667 & 2.279941 & 28.86433 \\
\hline Median & 0.014814 & 0.400000 & 0.975610 & 28.70925 \\
\hline Maximum & 1.184784 & 0.833333 & 24.03259 & 33.47373 \\
\hline Minimum & -0.147547 & 0.200000 & 0.029828 & 25.79571 \\
\hline Std. Dev. & 0.109141 & 0.103295 & 3.474901 & 1.594077 \\
\hline
\end{tabular}

Source: Results of data processing with E-views 10

Based on the descriptive statistical test results in accordance with table 1 shows the average (mean) and median values of the dependent variable namely earning management with a total sample of 177 samples, each at 0.020403 and 0.014814 . Whereas the highest value (maximun) shows 1.184784 and the lowest value (minimum) shows -0.147547. The value of the standard deviation of earnings 
management is 0.109141 , because the value of the standard deviation is greater than the average value (mean) indicating that the data are heterogeneous.

The value of corporate governance (X1) in this study uses proxy independent commissioners with a total of 177 samples that produce an average value (mean) of 0.410667 and a median value of 0.400000 . Whereas the highest value (maximun) shows a figure of 0.833333 owned by Unilever Indonesia Tbk (UNVR) in 2018 and the lowest value (minimum) indicates a figure of 0.200000 owned by PT Semen Baturaja (Persero) Tbk. (SMBR) in 2017. The value of the standard deviation in corporate governance is 0.103295 which is smaller than the mean (mean) so it can be concluded that there is a low variation between the highest value (maximun) and the lowest value (minimum) for that variable.

The value of information asymmetry (X2) in this study uses a total sample of 177 which results in an average value of 2.279941 and a median value of 0.975610 . Whereas the highest value (maximun) shows the figure of 24.03259 owned by PT Wilmar Cahaya Indonesia Tbk. (CEKA) in 2018 and the lowest value (minimum) shows a figure of 0.029828 owned by Gudang Garam Tbk. (GGRM) in 2017. The value of the standard deviation in information asymmetry is 3.474901, which is smaller than the mean (mean) so it can be concluded that there is a low variation between the highest value (maximun) and the lowest value (minimum) for that variable.

The value of firm size (X3) in this study uses 177 samples which results in an average value of 28,86433 and a median value of 28,70925. Whereas the highest value (maximun) shows the number of 33.47373 owned by Astra International Tbk. (ASII) in 2018 and the lowest value (minimum) shows a figure of 25,79571 owned by Pyridam Farma Tbk. (PYFA) in 2017. The value of the standard deviation in information asymmetry is 1.594077 which is smaller than the mean (mean) so it can be concluded that there is a low variation between the highest value (maximun) and the lowest value (minimum) for that variable.

\section{Panel Data Model}

There are three types of panel data estimation models used in the E-Views 10 application program, namely the common effect model, fixed effect model, and random effect model.

\section{Common Effect Model}

The common effect model is the simplest panel data model because its approach ignores the dimensions of space and time possessed by panel data. The results of the common effect model described in table 2 are as follows:

Table 2. Common Effect Model

\begin{tabular}{|c|c|c|c|c|}
\hline \multicolumn{5}{|l|}{ Dependent Variable: $\mathrm{Y}$} \\
\hline \multicolumn{5}{|c|}{ Method: Panel Least Squares } \\
\hline \multicolumn{5}{|c|}{ Date: $06 / 13 / 20$ Time: $20: 47$} \\
\hline \multicolumn{5}{|c|}{ Sample: 20162018} \\
\hline \multicolumn{5}{|l|}{ Periods included: 3} \\
\hline \multicolumn{5}{|c|}{ Cross-sections included: 59} \\
\hline \multicolumn{5}{|c|}{ Total panel (balanced) observations: 177} \\
\hline Variable & Coefficient & Std. Error & $\mathrm{t}$-Statistic & Prob. \\
\hline $\mathrm{C}$ & 0.075038 & 0.164951 & 0.454910 & 0.6497 \\
\hline $\mathrm{X} 1$ & 0.020228 & 0.080223 & 0.252151 & 0.8012 \\
\hline $\mathrm{X} 2$ & -0.002827 & 0.002545 & -1.111099 & 0.2681 \\
\hline $\mathrm{X} 3$ & -0.001957 & 0.005540 & -0.353320 & 0.7243 \\
\hline R-squared & 0.007666 & \multicolumn{2}{|c|}{ Mean dependent var } & 0.020403 \\
\hline Adjusted R-squared & -0.009543 & \multicolumn{2}{|c|}{ S.D. dependent var } & 0.109141 \\
\hline S.E. of regression & 0.109661 & \multicolumn{2}{|c|}{ Akaike info criterion } & -1.560514 \\
\hline Sum squared resid & 2.080402 & \multicolumn{2}{|c|}{ Schwarz criterion } & -1.488737 \\
\hline Log likelihood & 142.1055 & \multicolumn{2}{|c|}{ Hannan-Quinn criter. } & -1.531404 \\
\hline F-statistic & 0.445462 & \multicolumn{2}{|c|}{ Durbin-Watson stat } & 1.473731 \\
\hline Prob(F-statistic) & 0.720819 & & & \\
\hline
\end{tabular}

Source: Results of data processing with E-views 10 


\section{Fixed Effect Model}

Fixed effect model is a panel data model that is used by entering the individuality of each company by making intercepts that vary for each company with the assumption that the slop coefficient is constant for each company. The results of the fixed effect model described in table 3 are as follows:

Tabel 3. Fixed Effect Model

\begin{tabular}{|c|c|c|c|c|}
\hline \multicolumn{5}{|c|}{ Dependent Variable: Y } \\
\hline \multicolumn{5}{|c|}{ Method: Panel Least Squares } \\
\hline \multicolumn{5}{|c|}{ Date: $06 / 13 / 20$ Time: $20: 47$} \\
\hline \multicolumn{5}{|c|}{ Sample: 20162018} \\
\hline \multicolumn{5}{|l|}{ Periods included: 3} \\
\hline \multicolumn{5}{|c|}{ Cross-sections included: 59} \\
\hline \multicolumn{5}{|c|}{ Total panel (balanced) observations: 177} \\
\hline Variable & Coefficient & Std. Error & t-Statistic & Prob. \\
\hline C & -6.327992 & 1.855669 & -3.410087 & 0.0009 \\
\hline $\mathrm{X} 1$ & 0.136304 & 0.149735 & 0.910304 & 0.3646 \\
\hline $\mathrm{X} 2$ & -0.002872 & 0.002696 & -1.065237 & 0.2890 \\
\hline \multirow[t]{2}{*}{ X3 } & 0.218227 & 0.064644 & 3.375802 & 0.0010 \\
\hline & Effects Spe & ification & & \\
\hline \multicolumn{5}{|c|}{ Cross-section fixed (dummy variables) } \\
\hline R-squared & 0.520510 & \multicolumn{2}{|c|}{ Mean dependent var } & 0.020403 \\
\hline Adjusted R-squared & 0.266171 & \multicolumn{2}{|c|}{ S.D. dependent var } & 0.109141 \\
\hline S.E. of regression & 0.093494 & \multicolumn{2}{|c|}{ Akaike info criterion } & -1.632483 \\
\hline Sum squared resid & 1.005238 & \multicolumn{2}{|c|}{ Schwarz criterion } & -0.519934 \\
\hline Log likelihood & 206.4748 & \multicolumn{2}{|c|}{ Hannan-Quinn criter. } & -1.181276 \\
\hline F-statistic & 2.046525 & \multicolumn{2}{|c|}{ Durbin-Watson stat } & 2.760254 \\
\hline Prob(F-statistic) & 0.000489 & & & \\
\hline
\end{tabular}

Source: Results of data processing with E-views 10

\section{Chow Test}

The likelihood test (Chow test) is a test used to determine the right panel data model between a common effect model or a fixed effect model. Table 4 is the test results of the Likelihood test (Chow test) are as follows:

Tabel 4. Chow Test

\begin{tabular}{|l|l|l|l|}
\hline \multicolumn{2}{|l|}{ Redundant Fixed Effects Tests } & & \\
\hline Equation: Untitled & & \\
\hline Test cross-section fixed effects & & \\
\hline Effects Test & Statistic & d.f. & Prob. \\
\hline Cross-section F & 2.120682 & $(58,115)$ & 0.0003 \\
\hline Cross-section Chi-square & 128.738580 & 58 & 0.0000 \\
\hline
\end{tabular}

Source: Results of data processing with E-views 10

Based on table 4, the data processing results show that the Likelihood test (Chow test) produced a cross-section F probability value of 0.0003 and a Chi-square cross-section probability value of 0.0000 , which has a value smaller than 0.05 . So it can be concluded that the fixed effect model is better than the common effect model. Due to the most appropriate fixed effect model, the Hausman test will be carried out which has the aim to determine the best panel data model among the fixed effect models or random effect models.

\section{Hausman Test}

Hausman test is done to determine the right model between fixed effect model or random effect model. Table 5 shows the results of the Hausman test as follows: 
Tabel 5. Hausman Test

\begin{tabular}{|c|c|c|c|}
\hline \multicolumn{3}{|c|}{ Correlated Random Effects - Hausman Test } & \\
\hline \multicolumn{2}{|c|}{ Equation: Untitled } & & \\
\hline \multicolumn{3}{|c|}{ Test cross-section random effects } & \\
\hline Test Summary & $\begin{array}{l}\text { Chi-Sq. } \\
\text { Statistic }\end{array}$ & Chi-Sq. d.f. & Prob. \\
\hline Cross-section random & 13.881161 & 3 & 0.0031 \\
\hline
\end{tabular}

Source: Results of data processing with E-views 10

Based on table 5, the data processing results show that in the Hausman test the probability value of ramdom cross-section is 0.0031 , which has a value smaller than 0.05 . Therefore, H0 is rejected so it can be concluded that the fixed effect model is better than the random effect model. So from the three types of panel data model estimation, the fixed effect model is the best and most appropriate model for this research.

Data Analysis Results. Testing multiple linear regression analysis based on table 3, that is, the fixed effect model will produce a regression model equation. The regression equation is as follows:

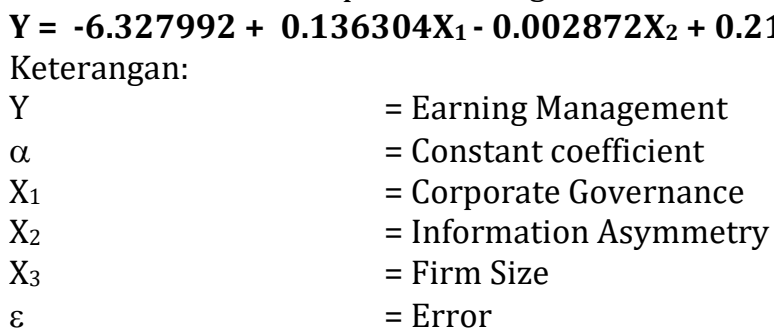

Based on the results of the regression equation formulated above, shows a constant coefficient of -6.327992 which means that the value of corporate governance, information asymmetry, and firm size is zero, then the value of earnings management is -6.327992 .

The value of the corporate governance variable coefficient that uses an independent commissioner proxy has a value of 0.136304 , which means that if corporate governance rises by one unit, earning management will increase by 0.136304 assuming the other independent variables namely information asymmetry and firm size are constant. Conversely, if corporate governance decreases by one unit, earnings management will decrease by 0.136304 assuming that the other independent variables, namely information asymmetry and firm size, are constant.

The value of the variable information asymmetry coefficient has a value of -0.002872 which means that if the information asymmetry increases by one unit, earning management will decrease by 0.002872 assuming that the other independent variables, corporate governance and firm size are constant. Conversely, if ownership structure decreases by one unit, earnings management will increase by 0.002872 assuming that the other independent variables, corporate governance and firm size are constant.

The value of the firm size variable coefficient has a value of 0.218227 , which means that if the firm size increases by one unit, earnings management will increase by 0.218227 assuming that the other independent variables namely corporate governance and information asymmetry are constant. Conversely, if firm size decreases by one unit, earnings management will decrease by 0.218227 assuming that the other independent variables, namely corporate governance and information asymmetry, are constant.

\section{Multiple Determination Coefficient Test $\left(\mathbf{R}^{2}\right)$}

The multiple determination coefficient $\left(\mathrm{R}^{2}\right)$ test is used to measure how much the model's ability to explain the dependent variable in a study. This test is conducted to determine how much the ability of corporate governance, information asymmetry, and firm size variables to explain the dependent variable earnings management. The results of the multiple determination coefficient test $\left(\mathrm{R}^{2}\right)$ are as follows: 
Tabel 6. Multiple Determination Coefficient Test $\left(R^{2}\right)$

\begin{tabular}{|c|c|}
\hline \multicolumn{2}{|l|}{ Dependent Variable: $Y$} \\
\hline \multicolumn{2}{|c|}{ Method: Panel Least Squares } \\
\hline \multicolumn{2}{|c|}{ Date: $06 / 13 / 20$ Time: $20: 49$} \\
\hline \multicolumn{2}{|c|}{ Sample: 20162018} \\
\hline \multicolumn{2}{|c|}{ Periods included: 3} \\
\hline \multicolumn{2}{|c|}{ Cross-sections included: 59} \\
\hline R-squared & 0.520510 \\
\hline Adjusted R-squared & 0.266171 \\
\hline
\end{tabular}

Source: Results of data processing with E-views 10

Table 6 shows the results that can be concluded that the results of the multiple coefficient of determination test (R2) by looking at the value of the Adjusted R-squared is equal to 0.266171 . This means that $26,6171 \%$ of the dependent variable, namely earnings management, can be explained by the independent variables, namely corporate governance, information asymmetry, and firm size. While the rest of 0.733829 or $73.3829 \%$ can be explained by other independent variables apart from the independent variables in this study.

Based on the results of the multiple determination coefficient test (R2), the value of the Adjusted R-squared in this study is close to zero. Therefore, the ability of independent variables namely corporate governance, information asymmetry, and firm size is very limited to be able to explain the dependent variable, namely earnings management because the value of the coefficient of determination is small.

T test. $\mathrm{T}$ test is done to measure how far the impact of an independent variable on the dependent variable by assuming other independent variables are constant. The criteria to be used in the test is with a confidence level of 0.95 and if it is less than 0.05 then the independent variable can significantly affect the dependent variable. Conversely, if the confidence level of 0.95 and if more than 0.05 then the independent variable significantly cannot influence the dependent variable. The following is table 7 , the results of the $t$ test as follows:

Tabel 7. $T$ Test

\begin{tabular}{|c|c|c|c|}
\hline \multicolumn{4}{|c|}{ Dependent Variable: Y } \\
\hline \multicolumn{4}{|c|}{ Method: Panel Least Squares } \\
\hline \multicolumn{4}{|c|}{ Date: $06 / 13 / 20$ Time: $20: 47$} \\
\hline \multicolumn{4}{|c|}{ Sample: 20162018} \\
\hline \multicolumn{4}{|c|}{ Periods included: 3} \\
\hline \multicolumn{4}{|c|}{ Cross-sections included: 59} \\
\hline \multicolumn{4}{|c|}{ Total panel (balanced) observations: 177} \\
\hline Variable & $\begin{array}{ll}\text { Coefficient } & \text { Std. Error } \\
\end{array}$ & t-Statistic & Prob. \\
\hline $\mathrm{C}$ & -6.327992 & -3.410087 & 0.0009 \\
\hline $\mathrm{X} 1$ & 0.136304 & 0.910304 & 0.3646 \\
\hline $\mathrm{X} 2$ & -0.002872 & -1.065237 & 0.2890 \\
\hline $\mathrm{X} 3$ & 0.064644 & 3.375802 & 0.0010 \\
\hline
\end{tabular}

Source: Results of data processing with E-views 10

Based on the results from table 7, it can be concluded that the independent variable of corporate governance (X1) which is proxied by the independent commissioner shows the probability value and $\mathrm{t}$ statistic value of 0.3646 and 0.910304 , respectively. The value of t-statistic shows a positive direction and a probability value of 0.3646 which is greater than 0.05 , so it can be said to be insignificant. Therefore, corporate governance does not have a significant effect on the dependent variable of this study, namely earnings management. This study has the same results as the results of research conducted by Wimelda and Chandra (2016); Muda et al, (2018) which shows that corporate governance in the independent commissioner proxy has no significant effect on earnings management. However, this study does not have the same results as the results of research conducted by Sajjad et al., (2019) states that corporate governance in the independent commissioner proxy has a significant effect on earnings management.

Information asymmetry (X2) shows the probability value and t-statistic value of 0.2890 and 1.065237, respectively. The value of t-Statistics shows a negative direction and a probability value of 0.2890 which is greater than 0.05 , so it can be said to be insignificant. Therefore, information asymmetry 
does not have a significant effect on the dependent variable of this study, namely earnings management. This study has the same results as the results of research conducted by Yulius, et al (2019) states that information asymmetry (information asymmetry) does not have a significant effect on earnings management. However, this study does not have the same results with the results of research conducted by Wiyadi, et al (2015) and Lita, et al (2018) states that information asymmetry has a positive and significant effect on earnings management.

Firm size (X3) shows the probability value of 0.0010 and the t-Statistic value of 3.375802 . The value of t-Statistics shows a positive direction and a probability value of 0.0010 which is smaller than 0.05 , so it can be said to be significant. Therefore, firm age has a positive and significant effect on the dependent variable of this study, namely earnings management. This study has the same results as the results of research conducted by (Ali et al 2015); (Nalarreason et al 2019) states that firm size has a significant positive effect on earnings management. However, this study did not have the same results as the results of research conducted by (Wahyono et al, 2019); (Mayasari et al, 2019) states that firm size does not have a significant effect on earnings management.

\section{F Test}

The $\mathrm{F}$ test can be used to show all the independent variables that will be included in this model have a simultaneous influence on the dependent variable. The criteria to be used in the $F$ test is with a confidence level of 0.95 and if it is less than 0.05 then the independent variable can significantly affect the dependent variable. Conversely, if the confidence level of 0.95 and if more than 0.05 then the independent variable significantly cannot influence the dependent variable. The following is table 8 , the results of the $\mathrm{F}$ test are as follows:

Tabel 8. F Test

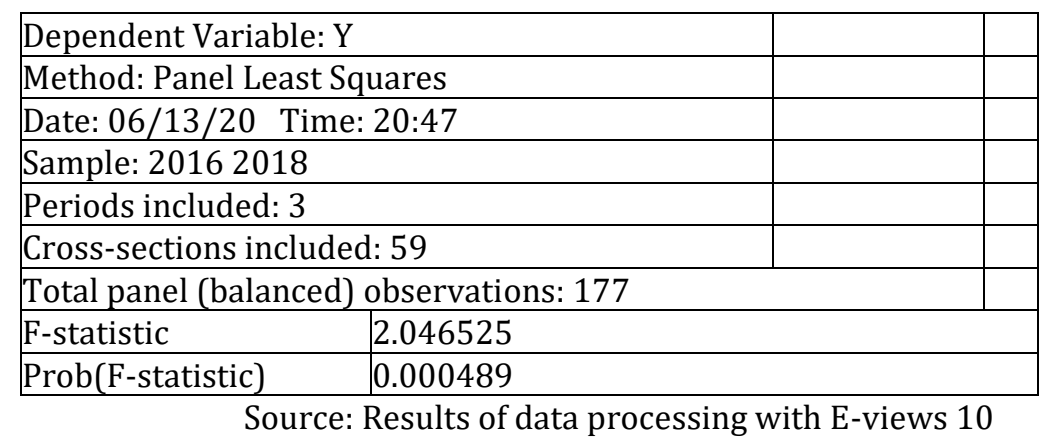

Table 8 shows the results of the F statistical test, the value of Prob (F-statistic) of 0.000489 , which means that the independent variables, corporate governance, information asymmetry, and firm size can affect the dependent variable, namely earning management simultaneously or together. The value of Prob (Fstatistic) of 0.000489 is smaller when compared with 0.05 . Therefore, the results of the F statistical test can be said that the regression model used to conduct research is feasible to use.

\section{DISCUSSION}

The purpose of this study was to determine the effect of corporate governance, information asymmetry, and firm size on earnings management. The subjects of this study were all manufacturing companies listed on the Indonesia Stock Exchange in 2016-2018.

\section{The effect of corporate governance on earnings management}

Corporate governance which is proxied by an independent commissioner has a regression coefficient of 0.136304 , the regression coefficient value has a positive sign which means that corporate governance has a positive influence on earnings management. The probability value in this study has a value of 0.3646 while the level of significance used to see whether it has a significant effect is 0.05 . The result is 0.3646 greater than 0.05 , which means that the probability value has insignificant results which indicate that corporate governance does not have a significant effect on earnings management in manufacturing companies listed on the Indonesia Stock Exchange (BEI) in 2016-2018. The insignificant results indicate that $\mathrm{H} 1$ in the research hypothesis which states that corporate governance has a significant positive effect on earnings management in manufacturing companies listed on the Indonesia Stock Exchange (BEI) in 2016-2018 was rejected. 
This study has the same results as the results of research conducted by Wimelda and Chandra (2016); Muda et al, (2018) which shows that corporate governance in the independent commissioner proxy has no significant effect on earnings management. However, this study does not have the same results as the results of research conducted by Sajjad et al., (2019) states that corporate governance in the independent commissioner proxy has a significant effect on earnings management.

These results state that corporate governance proxied by an independent commissioner does not have a significant effect on earnings management, this is because corporate governance owned by a large or small company, the company will still not influence management to conduct earnings management practices. An independent commissioner of a company acts as an outside commissioner so that it cannot influence the management to conduct earnings management practices.

\section{The effect of information asymmetry on earnings management}

Information asymmetry has a regression coefficient of -0.002872 , the value of the regression coefficient has a negative sign which means that information asymmetry has a negative effect on earnings management. The probability value in this study has a value of 0.2890 while the significance level used to see whether it has a significant effect is 0.05 . The result is 0.2890 greater than 0.05 , which means that the probability value has insignificant results indicating that information asymmetry does not have a significant effect on earnings management in manufacturing companies listed on the Indonesia Stock Exchange (BEI) in 2016-2018. The insignificant results show that $\mathrm{H} 2$ in the research hypothesis stating information asymmetry has a significant positive effect on earnings management in manufacturing companies listed on the Indonesia Stock Exchange (BEI) in 2016-2018 was rejected.

This study has the same results as the results of research conducted by Yulius, et al (2019) states that information asymmetry (information asymmetry) does not have a significant effect on earnings management. However, this study does not have the same results with the results of research conducted by Wiyadi, et al (2015) and Lita, et al (2018) states that information asymmetry has a positive and significant effect on earnings management.

These results state that information asymmetry does not have a significant effect on earnings management, this is due to the possibility of manager's mistake in presenting the previous financial statements, financial statements that are incomplete and not neutral so that the profits generated are not in accordance with applicable accounting provisions (Octifia et al, 2017).

\section{The effect of firm size on earnings management}

Firm size has a regression coefficient of 0.218227 , the value of the regression coefficient is a positive sign, which means firm size has a positive effect on earnings management. The probability value in this study has a value of 0.0010 while the level of significance used to see whether it has a significant effect is 0.05 . The result is 0.0010 smaller than 0.05 , which means that the probability value has a significant result which indicates that firm size has a significant influence on earnings management in manufacturing companies listed on the Indonesia Stock Exchange (BEI) in 2016-2018. Significant results indicate that H3 in the research hypothesis which states that firm size has a significant positive effect on earnings management in manufacturing companies listed on the Indonesia Stock Exchange (BEI) in 2016-2018 was received.

This study has the same results as the results of research conducted by (Ali et al 2015); (Nalarreason et al 2019) states that firm size has a significant positive effect on earnings management. However, this study did not have the same results as the results of research conducted by (Wahyono et al, 2019); (Mayasari et al, 2019) states that firm size does not have a significant effect on earnings management.

These results state that firm size has a significant positive effect on earnings management, this is because companies with large categories tend to have complex operational activities when compared to companies with small categories, so it might trigger earnings management activities in a company. In addition, large companies are more motivated to practice income smoothing, which is one form of earnings management activities because large companies have more political costs than small companies. These political costs can arise because a company has a high level of profitability, which can attract public attention (Moses, 1997 in Yanti and Setiawan, 2019).

\section{CONCLUSION}

The purpose of this research is to obtain information by conducting empirical testing on the influence of the independent variables of corporate governance, Information asymmetry, and firm size on the independent variable earnings management in manufacturing companies listed on the Indonesia Stock 
Exchange (BEI) in the 2016-2018 period. In this study the data collection techniques used are secondary data obtained from financial statements, company stock prices and joint stock price indexes on the official website of the Indonesia Stock Exchange (www.idx.co.id). In this study the population used is the company. manufacturers listed on the Indonesia Stock Exchange (BEI) in 2016-2018.

This study focuses the population in manufacturing companies because manufacturing companies have more current and fixed assets, so they are often used as targets for earnings management practices. In this study the sampling technique that can be used is purposive sampling by selecting samples based on several predetermined criteria. Earning management in this study was measured using proxy discretionary accruals (DA). Based on the results of research conducted on the effect of corporate governance, information asymmetry, and confirmation size where corporate governance and information asymmetry variables do not show a significant effect on earnings management. But the results of this study indicate that firm size variables have a positive and significant effect on earnings management.

In this study the test is based on data from the sample that is a descriptive statistical test and the test will then be conducted to choose which panel data model is the most appropriate to be selected in this study by passing the Likehood (Chow test) and Haumant test. Meanwhile, to test about a hypothesis can be through partial tests, simultaneous tests and testing the coefficient of multiple determination (Adjusted $\mathrm{R}^{2}$ ). Data collection and processing conducted in this study using Microsoft Excel 2013. Data processing that has been completed will be tested by using the E-views Version 10 program with the aim to provide an overview of the overall characteristics of the data that has been processed.

Based on the results of $t$ test shows that the independent variable of corporate governance (X1) which is proxied by the independent commissioner shows the probability value and the t-statistic value respectively 0.3646 and 0.910304 . The value of $t$-statistic shows a positive direction and a probability value of 0.3646 which is greater than 0.05 , so it can be said to be insignificant. Therefore, corporate governance does not have a significant effect on the dependent variable of this study, namely earnings management.

Information asymmetry (X2) shows the probability value and t-statistic value of 0.2890 and 1.065237, respectively. The value of t-Statistics shows a negative direction and a probability value of 0.2890 which is greater than 0.05 , so it can be said to be insignificant. Therefore, information asymmetry does not have a significant effect on the dependent variable of this study, namely earnings management.

Firm size (X3) shows the probability value of 0.0010 and the t-Statistic value of 3.375802 . The value of $\mathrm{t}$-Statistics shows a positive direction and a probability value of 0.0010 which is smaller than 0.05 , so it can be said to be significant. Therefore, firm age has a positive and significant effect on the dependent variable of this study, namely earnings management.

Based on the results of the F test shows that the value of Prob (F-statistic) of 0.000489 which means that the independent variables, namely corporate governance, information asymmetry, and firm size can affect the dependent variable, namely earning management simultaneously or together. The value of Prob (F-statistic) of 0.000489 is smaller when compared with 0.05 . Therefore, the results of the F statistical test can be said that the regression model used to conduct research is feasible to use.

Limitations contained in this study are in the form of: a) In this study only used three independent variables in testing earnings management namely corporate governance, information asymmetry, and firm size while there are several other factors that allow an influence on earnings management ( earnings management) that were not selected. b) This study only used a sample of manufacturing companies listed on the Indonesia Stock Exchange (IDX) but did not take a sample of companies in Indonesia as a whole that were outside the IDX to determine the effect of the independent variables on the dependent variable during the study. c) This research is only limited to the method used in calculating earnings management, which is an accrual-based method. In addition there are other methods that are not selected, which are real-based methods that can be seen from the side of the company's operational activities. d) The period specified in this study only uses the period in 2016-2018 so that the explanation of the results obtained during the study is limited to the study period and the samples taken are also limited which can only use samples in the relevant year ie 2016-2018.

There are several suggestions that can be given to further research based on the limitations that have been stated previously, namely as follows: a) For further research it is recommended to be able to take independent variables that reflect an influence on earnings management activities in manufacturing companies in Indonesia such as: financial distress, firm age, the size of the board of commissioners and others. b) Further research can consider taking more samples, namely taking samples of manufacturing companies in Indonesia as a whole, which results can represent all manufacturing companies in Indonesia. c) Future research can consider choosing a real-based method of doing earnings management calculations related to company operations. d) For further research, it is expected to be able to choose the period in which the manufacturing company has issued audited financial statements on the IDX so that 
the sample taken can be more numerous or can add more periods so that it can produce more accurate research.

\section{REFERENCES}

Abdillah, S.Y., Susilawati, R. A. E., \& Purwanto, N. (2016). Pengaruh Good Corporate Governance Pada Manajemen Laba (Studi Empiris Pada Perusahaan Manufaktur Yang Terdaftar Di Bursa Efek Indonesia Tahun 2013-2014). Program Studi Akuntansi, Fakultas Ekonomika Dan Bisnis Universitas Kanjuruhan, Malang.

Agustia, Y. P., \& Suryani, E. (2018). Pengaruh Ukuran Perusahaan, Umur Perusahaan, Leverage, dan Profitabilitas Terhadap Manajemen Laba (Studi Pada Perusahaan Pertambangan yang Terdaftar di Bursa Efek Indonesia Periode 20142016). Program Studi Akuntansi, Fakultas Ekonomi Dan Bisnis, Universitas Telkom, Bandung.

Arianti, E., Amrul, R., \& Wijayanto, S.A. (2020). Pengaruh Kompensasi Bonus, Debt Covenant, dan Firm Size Terhadap Earning Management Pada Perusahaan Manufaktur. Sekolah Tinggi Ilmu Ekonomi AMM, Mataram.

Asri, R. W. (2020). A Literature Review: Positive Accounting Theory (PAT). SSRN Electronic Journal (DO10.2139/ssrn.3523571), PP. 1-10.

Bahana Takbir Aljana, A. P. (2017). Pengaruh Profitabilitas, Struktur Kepemilikan, Dan Kualitas Audit Terhadap Manajamen Laba. Journal of Accounting, Vol.6, No.3, PP.1-15.

Deddy Kurniawansyah, S. K. (2018). Teori Agency Dalam Pemikiran Organisasi: Pendekatan Positivist dan Principle-Agen. Jurnal Riset Akuntansi dan Bisnis Airlangga Vol. 3. No. 2, PP.435-446.

Donald E. Kieso, J. J. (2019). Intermediate Accounting , 17 th Edition. Newyork: John Wiley \& Sons.

Febrianto, A. I. (2017). Pengaruh Asimteri Informasi dan Ukuran Perusahaan Terhadap Manajemen Laba. Balance Vocation Accounting Journal, Vol1, No.2, PP. 1-11.

Gayatri, P. J. (2016). Pengaruh Ukuran Perusahaan Terhadap Manajemen Laba Dengan Pengungkapan Corporate Social Responsibility Sebagai Variabel Intervening. E-Jurnal Akuntansi Universitas Udayana,Vol.14.No.1,PP.511-538.

Ghozali, I. \& Ratmono, D. (2017). Analisis Multivariat dan Ekonometrika dengan Program Eviews 10 (Edisi 2). Semarang: Badan Penerbit Universitas Diponegoro.

Ida Ayu Jayatri Pramesti, I. G. (2017). Pengaruh Asimetri Informasi, Leverage dan Kepemilikan Manajerial Pada Manajemen Laba. E-Jurnal Akuntansi Universitas Udaya, Vol. 21, No.1, PP.200-226.

Ikatan Akuntan Indonesia (IAI). Standar Akuntansi Keuangan revisi 2016. (2016). Salemba Empat. Jakarta.

Indracahya, E., \& Faisol, D. A. (2017). The Effect Of Good Corporate Governance Elements, Leverage, Firm Age, Company Size And Profitability On Earning Management (Empirical Study Of Manufacturing Companies In BEI 2014 - 2016). Universitas Mercu Buana.

Kadek Marlina Nalarreason, S. T. (2019). Impact of Leverage and Firm Size on Earnings Management in Indonesia. International Journal of Multicultural and Multireligious Understanding, Vol. 6, PP.1924.

Linda Wimelda, A. C. (2018). Opportunistic Behavior, External Monitoring Mechanisms, Corporate Governance, and Earnings Management. Accounting and Finance Review, Vol.3, No.1, PP.44-52, 44-52.

Lita Yulita Fitriyani, S. S. (2018). The Influence of Information Asymmetry,Independent Commisioner Board, Audit Committee,Managerial Ownership, and Firm Size on Earning Management. Journal of Engineering and Applied Sciences, Vol.13, Iss.10, PP.8148-8152.

Man, Chi-Keung., and Wong, Brossa. (2013). Corporate Governance and Earnings Management: A Survey of Literature. Journal of Applied Business Research.

Manggau, A. W. (2016). Pengaruh Asimetri Informasi dan Ukuran Perusahaan Terhadap Manajemen Laba Pada Perusahaan Pertambangan Yang Terdapat di Bursa Efek Indonesia. Jurnal Ekonomi dan keuangan, Vol.13, No,2, PP.103-114.

Mayasari, A. Y. (2019). The Influence of Corporate Governance, Companay Size, and Leverage Toward Earning Management. Jurnal Akuntansi Trisakti,Vol.6,No.1,PP.19-30.

Nur Asyiroh, U. H. (2019). Firm Size, Leverage, Profitabilitas, Free Cash Flow, Good Corporate Governance dan Earning Management : Studi Pada Perusahaan Sektor Infrastruktur dan Transportasi di Indonesia. Jurnal Ilmu Manajemen,Vol.7,No.3,PP.726-739.

Oktifia Aristiani, S. G. (2017). Pengaruh Prudence Terhadap Asimetri Informasi Dengan Kualitas Laba Sebagai Variabel Moderasi. Journal of Accounting \& Finance, Vol.13, No.2, PP.62-82. 
Organisation for Economic Co-Operation and Development (OECD). (2004). OECD Principles of Corporate Governance. www.oecd.org/dataoecd/32/18/31557724.pdf.

Puspitaningtyas, Z. (2015). Prediksi Risiko Investasi Saham. Yogyakarta: Griya Pandiva.

Setiawan, N. P. (2019). Pengaruh Asimetri Informasi, Ukuran Perusahaan, Leverage dan Profitabilitas pada Manajemen Laba. E-Jurnal Akuntansi Universitas Udayana,Vol.27,No.1,PP.708-736.

Suryani, Y. P. (2018). Pengaruh Ukuran Perusahaan, Umur Perusahaan, Leverage, dan Profitabilitas Terhadap Manajemen Laba. Jurnal Aset (Akuntansi Riset),Vol. 10,NO (1),PP. 63-74

Usman Ali, M. A. ( 2015). Impact of Firm Size on Earnings Management;A Study of Textile Sector of Pakistan. European Journal of Business and Management,Vol.7, No.28,PP.47-56.

Wahyono, A. N. (2019). The Effect of CSR Disclosure,Corporate Governance Mechanism, Auditor Independence, AuditorQuality, and Firm Size on Earning Management. Jurnal Riset Akuntansi dan Keuangan Indonesia,Vol.3,No.3,PP.156-170.

Widyaningsih, H. (2017). Pengaruh Corporate Governance Terhadap Manajemen Laba. STIEBBANK Yogyakarta.

Wimelda, L., \& Chandra, A. (2018). Opportunistic Behavior, External Monitoring Mechanisms, Corporate Governance, and Earnings Management. Trisakti School of Management, Jl. Kyai Tapa No. 20, 11440, Jakarta, Indonesia.

Wirakusuma, D. K. (2016). Pengaruh Perencanaan Pajak, Kepemilikan Manajerial dan Ukuran Perusahaan Terhadap Praktik Manajemen Laba. E-Jurnal Akuntansi Universitas Udayana,Vol.14,No.3,pp.1555-1583.

Wiyadi, R. T. (2015). The Effect of Information Asymmetry, Firm Size, Leverage, Profitability and Employee Stock Ownership on Earnings Management With Accrual Model. International Journal of Business, Economics and Law, Vol. 8, Iss.2, PP. 21-30.

Yulius Kurnia Susanto, A. P. (2019). Earnings Management: ESOP and Corporate Governance. Academy of Accounting and Financial Studies Journal, Vol.23, PP.1-13. 